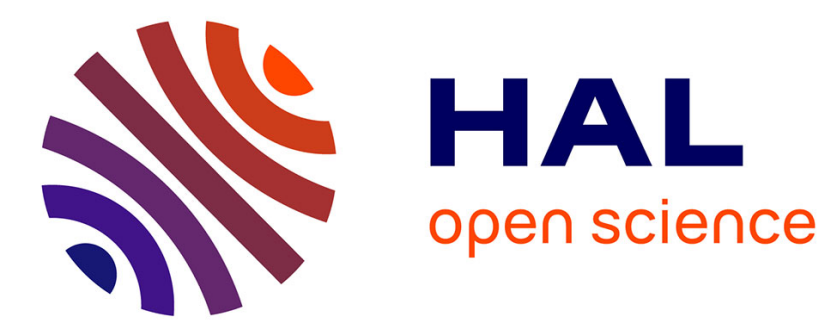

\title{
Very late relapse of dapsone-induced methaemoglobinemia
}

Guillaume Moulis, Haleh Bagheri, Jacques Saint Martory, Pascale Bernard, Jean-Louis Montastruc

\section{- To cite this version:}

Guillaume Moulis, Haleh Bagheri, Jacques Saint Martory, Pascale Bernard, Jean-Louis Montastruc. Very late relapse of dapsone-induced methaemoglobinemia. European Journal of Clinical Pharmacology, 2010, 66 (6), pp.645-646. 10.1007/s00228-010-0801-x . hal-00612991

\section{HAL Id: hal-00612991 https://hal.science/hal-00612991}

Submitted on 2 Aug 2011

HAL is a multi-disciplinary open access archive for the deposit and dissemination of scientific research documents, whether they are published or not. The documents may come from teaching and research institutions in France or abroad, or from public or private research centers.
L'archive ouverte pluridisciplinaire HAL, est destinée au dépôt et à la diffusion de documents scientifiques de niveau recherche, publiés ou non, émanant des établissements d'enseignement et de recherche français ou étrangers, des laboratoires publics ou privés. 


\title{
Very late relapse of dapsone-induced methaemoglobinemia
}

\author{
Guillaume Moulis • Haleh Bagheri • \\ Jacques Saint Martory • Pascale Bernard • \\ Jean-Louis Montastruc
}

Received: 5 February 2010 /Accepted: 8 February 2010/Published online: 13 March 2010

(C) Springer-Verlag 2010

Keywords Dapsone $\cdot$ Methaemoglobinemia

Dapsone, a sulfone active against a wide range of bacteria, is mainly used for Mycobacterium leprae. Moreover, because of its immunosuppressive effect, it is used for many auto-immune diseases [1]. Methaemoglobinemia is an expected adverse drug reaction of dapsone, seldom symptomatic. Long-term administration of dapsone at standard doses (100 mg/day) results in methaemoglobinemia in about $15 \%$ of patients [2]. When symptomatic

\section{G. Moulis}

Service de Médecine Interne, Centre Hospitalier Universitaire de Toulouse, Université Paul-Sabatier,

Toulouse, France

e-mail: gmoulis@hotmail.com

G. Moulis $\cdot$ H. Bagheri · J.-L. Montastruc

Service de Pharmacologie Clinique, Centre Midi-Pyrénées de Pharmacovigilance, de Pharmacoépidémiologie et d'Informations sur le Médicament, Unité de Pharmacoépidémiologie EA 3696, Centre Hospitalier Universitaire de Toulouse, Université de Toulouse, Faculté de Médecine,

Toulouse, France

J. Saint Martory

Service de Médecine Interne, Centre Hospitalier d 'Albi, Albi, France

P. Bernard

Service de Pharmacie, Clinique de l'Union,

Saint-Jean de l'Union, France

G. Moulis $\cdot H$. Bagheri $(\bowtie)$

Service de Pharmacologie Clinique, Faculté de Médecine,

37 Allées Jules-Guesde,

31000 Toulouse, France

e-mail: bagheri@cict.fr (dyspnea, cyanosis, neurological disorders), methaemoglobinemia is treated with methylene blue (1-2 $\mathrm{mg} / \mathrm{kg})$ [3]. Rebounds have been described after dapsone withdrawal, with a maximum delay of $64 \mathrm{~h}$ [4]. We report a case of dapsone-induced methaemoglobinemia which relapsed 10 days after drug withdrawal.

A 25-year-old woman was diagnosed with systemic lupus erythematosus in January 2009. Organs involved were skin and joints, and hydroxychloroquine alone was prescribed. In October 2009, she developed a bullous dermatitis and dapsone was added to hydroxychloroquine on 26 October 2009. About 1 month later, on 24 November, she was admitted to the hospital for severe dyspnea. Physical examination was normal except for cutaneous cyanosis. Chest computed tomography and electrocardiogram were normal. Arterial blood gas analysis showed $\mathrm{pH}$ : 7.63, $\mathrm{PaO}_{2}: 110 \mathrm{mmHg}, \mathrm{PaCO}_{2}: 15 \mathrm{mmHg}$, haemoglobin: $11 \mathrm{~g} / \mathrm{dL}, \mathrm{SaO}_{2}$ : 99.1\%; methaemoglobin: 17\%. Methylene blue $(2 \mathrm{mg} / \mathrm{kg})$ was injected intravenously. Twenty minutes later, the patient was asymptomatic and arterial methaemoglobin was 4\%. Dapsone was discontinued and the patient left the hospital on 26 November. Ten days later, she consulted for relapse of dyspnea. Arterial blood gas analysis showed methaemoglobin at $14 \%$. No symptomatic treatment was done and methaemoglobin rate decreased spontaneously to $5 \%$ the next day. Hydroxychloroquine was stopped. The compliance of the patient was not doubtful, and no other cause of intoxication causing methaemoglobinemia was found.

Methaemoglobinemia in dapsone intoxication is due to the ability of dapsone hydroxylamine, a metabolite of the drug, to react with haemoglobin $\left(\mathrm{Fe}^{2+}\right)$ to form methaemoglobin $\left(\mathrm{Fe}^{3+}\right)$ [5]. Methaemoglobin is unable to bind dioxygen, which results in functional anaemia. The clinical 
symptoms depend on the level of methaemoglobinemia: asymptomatic if less than $15 \%$; cyanosis for levels above $15 \%$; headache, dyspnea, nausea, tachycardia, weakness for levels above $20 \%$; coma for levels above $45 \%$; and a high mortality rate is associated with levels above $70 \%$ [6]. Methylene blue could act as a cofactor of the enzyme NADPH-methaemoglobin reductase, converting a methaemoglobin molecule into a haemoglobin molecule.

Regarding the relationship with hydroxychloroquine, the delay of onset of methaemoglobinemia seems too long (10 months). To our knowledge, no observation of hydroxychloroquine-induced methaemoglobinemia has been reported in the literature. We only found some cases of chloroquine-induced methaemoglobinemia, generally revealing a genetic deficiency in NADPH-cytochrome b5 reductase $[7,8]$.

The delay of the methaemoglobinemia relapse after dapsone withdrawal may be explained by the long elimination half-time (20-30 h) [9], which also depends on genetic polymorphisms of cytochrome P450, particularly CYP2E1, which produces the hydroxylamine metabolite [10]. Furthermore, a linear relationship has been demonstrated between hydroxylamine-dependent methaemoglobin formation and reduction of hydroxylamine to dapsone in human red blood cells in vitro [11]. According to these authors, there may be a cycle between hepatic oxidation of dapsone to its hydroxylamine and reduction to the parent amine within the red cells, which may lead to re-oxidation by hepatic cytochrome $\mathrm{P} 450$ and thus contribute to the persistence of the drug in vivo.
These pharmacokinetic particularities leading to a late relapse of dapsone-induced methaemoglobinemia should be kept in mind by physicans for appropriate treatment.

\section{References}

1. Anonymous (2007) Dapsone. In: Sweetman SC (ed) Martindalethe complete drug reference, 35th ed. Pharmaceutical Press, London, pp 234-236

2. Coleman MD, Rhodes LE, Scott AK et al (1992) The use of cimetidine to reduce dapsone-dependent methaemoglobinaemia in dermatitis herpetiformis patients. Br J Clin Pharmacol 34:244-249

3. Turner MD, Karlis V, Glickman RS (2007) The recognition, physiology, and treatment of medication-induced methemoglobinemia: a case-report. Anesth Prog 54:115-117

4. MacDonald RD, MacGuigan MA (1997) Acute dapsone intoxication: a pediatric case-report. Pediatr Emerg Care 13:127-129

5. Kramer P, Glader B, Li T (1972) Mechanism of methaemoglobin formation by diphenylsulphones. Biochem Pharmacol 21:1265-1274

6. Curry S (1982) Methemoglobinemia. Ann Emerg Med 11:214 221

7. Sharma N, Varma S (2003) Unusual life-threatening adverse drug effects with chloroquine in a young girl. J Postgrad Med 49:187

8. Cohen RJ, Sachs JR, Wicker DJ, Conrad ME (1968) Methemoglobinemia provoked by malaria prophylaxis in Vietnam. N Engl J Med 279:1127-1131

9. Zuidema J, Hilbers-Modderman E, Merkus F (1986) Clinical pharmacokinetics of dapsone. Clin Pharmacokinet 11:299-315

10. Mitra A, Thummel K, Kalhorn T, Kharasch E, Unadkat J, Slattery J (1995) Metabolism of dapsone to its hydroxylamine by CYP2E1 in vitro and in vivo. Clin Pharmacol Ther 58:556-566

11. Coleman MD, Jacobus DP (1993) Reduction of dapsone hydroxylamine to dapsone during methaemoglobin formation in human erythrocytes in vitro. Biochem Pharmacol 45:1027-1033 